\title{
Election and Security Challenges in Nigeria: Experience from the Niger Delta 1999-2015
}

\author{
Roger .T. Akpan \\ Department of Political and Administrative Studies, University of Port Harcourt, Nigeria
}

\begin{abstract}
Since the attainment of political independence in 1960 and return to democracy in 1999, elections in Nigeria have remained a security threat.The question of loss of lives, carting away of ballot boxes, shootings and killings have been common feature of elections. The assertion that election could be transformative and credible have been contestable. This article examines election and security challenges drawing from the Niger Delta experience. The study is framed around the human security theoretical framework and focused within the period 1999 to 2015.This period is important as a lot of studies have not been already conducted in this research area within this time frame following nascent Democracy. It identified divergent insecurity threats associated with the conduct of elections including conceptual and theoretical issues surrounding election and security and made some recommendations.
\end{abstract}

Keywords: Election, Security, Democracy, Development, Niger Delta

\section{INTRODUCTION}

Electoral security challenges have been a major problem to the conduct of free, fair and credible elections in the Niger Delta since the return to democracy in 1999. This has taken several dimensions including shootings in elections, resurgence of armed gangs, carting away of ballot boxes, buying of votes, arms race in the electoral process, ganstarism, thuggery and hooliganism ( Olurode,2013).Some of the most critical challenges of electoral insecurity include the killing of people (Fischer, 2002;Human Rights Watch,2004;Aniekwe and Kushie,2011).The Niger Delta according to recent data has been confronted with this growing electoral security problem which threatens peaceful coexistence and social harmony( Human Rights Watch,2007). Several studies have pointed out the persistent insecurity threats posed by these activities associated with elections such as ballot box snuffling.

Thus, election tensions have exacerbated in the Niger Delta taking several dimensions which tend to degenerate into palpable anxiety in relation to pre-existing community conflicts, which are common in several parts of the Niger Delta. For instance, there have been the existence of local cult groups in several parts of the region which perpetuate election violence in most communities in the region. These groups are often recruited by the political elite as machinery to rig elections. In Rivers State there is the existence of the Icelanders and the Greenlanders. These rival cult groups have caused several terror resulting in electoral crisis since the return to democracy in 1999(Olurode, 2013).

These violence have been conceptualized within the pre, during and post -election experiences in the region (Aniekwe and Kushie, 2011).Of much relevance to this study is the insecurity threats they pose to humanity. Thus, the Niger Delta experience suggests that electoral violence and fraud has been on the increase. There have been, the dominance of extra-legal political backers (commonly referred to in Nigeria as "godfathers"), ballot-box stuffing, ballot-box stealing, and the nearly routine threat of kidnappings and other security breaches(Onwudiwe and Berwind-Dart, 2011).

In the 1999 and 2003 election part of the violence and insecurity in the conduct of the election in Delta State was as a result of the deployment of militants and cult groups. Aniekwe and Kushie, (2011)contend that the acceptance of the 1999 election results marred by massive rigging was choiceness as there was no further options after over 30 years of military dictatorship.

Similarly, in the 2003 elections Aniekwe and Kushie (2011) argued that the level of acceptance was not based on its freeness but one of choosing from bad and worse. They argued that in 2003 election, 
Nigerian witnessed an unprecedented level of electoral violence. Electoral fraud ranges from ballot stuffing, intimidation, killing, assassination etc. They summarized that the election was it was a triumph of violence. For instance, the 2003 was marred by massive violence (HRW, 2003) and widely described as the worst election since the return to democracy in 1999(Human Rights Watch, 2007).

In the 2007 election, violence took several dimensions in the region which deepened including physical assaults and multiple voting in major states in the Niger delta considered the strongholds of the PDP (Igbuzor,2010). The massive violence in the 2007 election in the Niger Delta as reported by the Human Rights Watch was contested as either "election" or "selection". As the breakdown of law and order and the guiding principles of credible election was evident (Human Rights Watch, 2007).

In 2009, President Yar'Adua granted amnesty to the militants to douse political and economic tension in the region. Despite the amnesty programme, post amnesty elections in the Niger Delta have been marred by violence and insecurity (Aniekwe and Kushie, 2011).

The 2011 general elections offered indications that better managed elections can be more peaceful. Despite such recorded success, the Niger Delta has been known to be a volatile and conflict prone region (HRW, 2011). Part of the electoral violence in the region has been an attribute of resurgence of post amnesty militancy culminating into youth restiveness in the region as the youths were recruited by the political elites to unleash electoral terror and violence against opposition parties.

This study is set within the period 1999 to 2015. It focuses on the Niger Delta region. Since the return to democracy in 199 elections in the Niger Delta have been characterized with security threats notably electoral violence it argues that despite nascent democracy, the intricate dynamics of the patterns of Nigeria's elections have been riddled with massive security threats which have not been given adequate scholarly attention, particularly in the context of the implications of the security threats on political and economic development of Nigeria. The article contends that the absence of adequate scholarly attention to the issues of election and security does not account for the political and economic realities of Nigeria's electoral processes and development .For instance, Garuba (2007) explains salient issues associated with instability in Nigeria's pattern of elections, encompassing massive electoral frauds, the conception and practice of politics as warfare, the lack of continuity in the political platforms used by members of the political class, high levels of opportunism and the mobilization of ethnic identities as the basis for defining the legitimacy of claims to political power, suggesting that this has resulted in "transition without change". These issues which constitute security threats are some of the key factors this study seeks to examine. The rest of the paper is structured as follows; theoretical framework, conceptual issues, the Niger Delta experience, conclusion and recommendations.

\section{THEORETICAL FRAMEWORK}

There are competing explanations and theoretical frameworks in the study of elections, security challenges and development in Nigeria. Most of these theories such as the conflict theory, the elite theory, the functionalist theory etc are useful for electoral and security studies but particularly inadequate to account for the changing realities of the dynamics of election induced insecurity particularly with direct effects on both human existence and the entire social system. This has made the need for a theoretical framework that links the dynamics of election to human security critical. The human security theory is the most plausible framework for this study. This is informed by the fact that the basis of democracy is to guarantee and protect the safety and rights of the citizenry(Diamond, 1997), the human security theory interrogates the extent liberal democracy is achieving such feat particularly at the individual level(Klare, 1996).

As democracy and elections are framed around human political behaviour and interactions, the understanding of the guarantee of human security in the quest for political power becomes elucidated within the understanding of the human security debate.

Against this background, the suitability of human security theory is based on two key considerations: first, on the insights it provides through its key assumptions for explaining issues related to electoral violence and security at the micro level which aptly fits into the overall objective of this work, second, for its strides in unravelling the developmental and methodological issues associated with the study which is largely qualitative and descriptive.

Insecurity of lives has been a direct consequence of electoral violence in Nigeria. 
In Western Nigerian States of Oyo, Ondo, and parts of Eastern Nigerian States of Enugu, Ebonyi, Imo and Abia and the coastal Niger Delta States of Rivers, Bayelsa and Delta, there were reports of intense political violence (HRW, 2011). Same was reported of Lagos, Ekiti and Kano in northern Nigeria, reports of high profile killings abounded. The unofficial death toll during the election was estimated by various observers to be as high as 200(Zasha, Mustapha and Meyer, 2007).

Don Hubert (2001,p.161)argues that while the term "human security" may be of recent origin, the ideas that underpin the concept are far from new for more than a century -at least, since the founding of the International Committee of the Red Cross in the 1860s-a doctrine based on the security of people has been gathering momentum. Hubert (2001) argues that the core elements of human security were formulated in the 1940s in the UN Charter, the Universal declaration of Human Rights and the Geneva Convention.

The understanding of the micro level analysis of security at the individual level has attracted recent scholarly attention (UN, 1994; Martin and Owen, 2010). This is suitable to examine the logic of election, insecurity and development as human being is at the center of election. At the end of the Cold War human security became an increasing concern as the state -centric notion of security within territorial boundaries and interstate security threats seemed to have ebbed (Klare, 1996). Essentially, the primacy of security of the people becomes increasingly important against the State and territorial boundaries which had increasingly disappeared following globalization(Klare, 1996; Hubert, 2001).Thus, the post- Cold Warera saw the emergence of a world order where the State no longer faces the perverse threat of proliferation of nuclear weapons rather the challenges of human existential realities became paramount(UN, 1994; ul Hag, 1995;Klare, 1996;Jolly and Ray, 2006,p. 34; Debiel and Werthes, 2006).

The human security thesis was popularized by the United Nations Development Programme (UNDP) in its 1994 Human Development Report (UNDP1994). The report examined security from human dimensions and provided 'New Dimensions of Human Security'. This unit level analysis of security which is a departure from the traditional macro level analysis from a micro level analysis encompasses, the protection of the lives of the coon people which have been elusive in the security debate (UNDP, 1994). Beyond this in specific terms, the report outlined seven distinct classification of security including; economic, food, health, environmental ,personal, community and political.

This was reinforced in the ongoing debate on "redefinition of security". Klare (1996) builds on the UNDP(1994)reports and expanded the theoretical understanding of the human security debate. Klare (1996)argues that the human security was among "the new global schisms" pointing out that " the major international schisms of the twenty first century will not be security of the state or security at the territorial level rather security of lives at the individual level".

Thus, the resurgence of new wars, local conflicts, crimes, intra state conflicts, terrorism, electoral violence and crisis, including civil and ethnic wars ravaged human populations as they pose threats to human security. These "new wars" -have also been attributed to the resurgence of globalization and the emergence of intractable nationalisms -perpetuated inequality and increased criminal activities and resurgence of what Kaldor $(1999,2007$, p. 6) termed " illegal economies". This was further elucidated in the broader context of linking development and security-in particular emphasizing the transformation and advancement of the individual as the basis of the security paradigm (UN, 2004).

In recent scholarships, the concept and theory of human security has been examined from a number of perspectives to arrive at definitional and conceptual goals (Khong, 2001; Kaldor, 2007; Tadjbakhsh and Anuradha, 2007; Fukuda-Parr and Messineo, 2012). This divergent theoretical explorations have rekindled increasing debates to deepen the study and understanding the fundamental assumptions of the human security. These have largely been party of recent debates linking sustainable human development to security studies (Martin and Owen, 2010).

The theoretical and policy relevance of the human security have thus received increasing attention among in local and global discourses (Martin and Owen, 2010). In 2001, the Commission on Human Security (CHS) was established to bolster the human security paradigm. Headed by Sadaka Ogata and Amartya Sen, among its several objectives the Commission was envisioned to;

1) "mobilize support and promote greater understanding of human security,

2) Develop further the concept as an operational tool, and 
3) Outline a concrete action plan for its implementation."

The Commission in its report reaffirmed the goal of human security;

"to protect the vital core of all human lives in ways that enhance human

freedoms and human fulfilment... protecting fundamental freedoms...

protecting people from critical (severe) and pervasive (widespread) threats

and situations" (CHS, 2003).

Mahbub ul Haq (1995) aptly reinforced the basis of human security and argued that;. "Security will be interpreted as: security of people, not just territory. Security of Individuals"

\section{ELECTION AND SECURITY: CONCEPTUAL ISSUES}

There are clearly difficulties in understanding and conceptualizing dynamics of prevailing electoral insecurity. A situation in which electoral chaos dominates the electoral process, this undoubtedly causes both policy and analytical problems for scholars who recognize election to be an organized system of choosing political office holder as representatives of the people (Alapiki, 2000). However the separation of security from election is inherently problematic as there is inherent interrelationship. Since the viability of the electoral system is determined by the political environment, election should be termed free, fair and credible to the extent that security is maintained in line with stipulated electoral guidelines, law and order.

Election is a creation of the Nigerian colonial state. It is tied to the quest for political office and power acquisition. In post- colonial Nigeria, studies on election and security have emerged to offer a serious challenge to the dynamics of electoral system in Nigeria (Ogundiya and Baba, 2005; Mohammed, 2007), which largely seeks to investigate the institutional and individual apparatus deployed in the conduct of elections, and in particular the extent dominant power relations and elite interest results in violence and its security implications to the wider development of the society.

In recognition of the complex nature of election, there have been divergent understanding and conceptual exploration of the term leading to a number of useful debates on the failure of the Nigerian State to conduct free, fair, credible and violent free elections since the return to democracy.

The poor transition debate argues that election has largely failed to be transformational due to inadequate transition (Diamond, 1997).The contention has been that both the political office seekers and the electorates are rarely given adequate education on the function and basis for elections resulting in poor conduct of elections. Diamond (1997) recounts that the return to democracy in most developing countries has been largely a "transitory phase" in which through repeated practices democracy deepening and consolidation could be achieved. In this particular context, the electorates directly or indirectly elect their representatives who are accountable to them. Beyond this ideal notion, the basis of the argument is that the electorates are stakeholders in the electoral process. In our case analysis and in the particular case of the Niger Delta political trajectories and literature creating such linkages seem less lucid.

The reason for the renewed interest in election and security is perhaps informed by the panic and fear that arises in the polity whenever election comes up and in particular the problem it has created towards evolving a true democracy in which the wishes of the people could be allowed to prevail untampered by the elite whose political interests are often paramount. This has often resulted in the conceptualization of election within the context of violence and its possible effects on democracy consolidation. For instance, Ogundiya and Baba (2005) argued that electoral violence in Nigeria has been a central factor in evaluating the prospects and challenges of democracy consolidation in Nigeria. They chronicled a number of electoral crisis and violence pointing to the relevance of security. This trend also partly accounts for the increasing pressure within Nigeria for free, fair and credible elections. Thus, the return to democracy had opened to a number of political trends in Nigeria such as multi-party system, periodic elections, novel electoral enlightenment or voter education suggestive of democracy resurgence. Beyond these, how nascent democracy has fostered transparency in elections is less conceptualized.

A major concern is how election could redirect the political orientation of both political office seekers and the electorates in line with the changing political system created by democracy. 
It becomes important to examine what the literature is saying about election in Nigeria and understand its salient implications for development and policy options.

At the conceptual level, there are divergent terminological use of the term election in the literature. Most debates point out that election is central on selecting public office seekers and beyond that determines the quality of government. Egwu $(2014$, p.1) recounts that "elections lie at the heart of representative democracy and constitute a mirror of the peoples understanding and appreciation of democratic norms". A number of factors determine the credibility or otherwise of elections which calls for closer look at the dynamics of the conduct of elections and in particular, how available literature is saying about the term election.

To capture these conceptual debates, research on election applies a wide range of issues, stemming from various disciplinary backgrounds and operating on various levels of government notably ward, local, state and national. While this divergent background makes it difficult to adopt a one for all conceptual perspective of election, particular attention is paid to attempts at conceptual clarifications which could be useful to create novel insights. Gwinn and Norton (1992) argue that election is the formal process of selection of a person for public office or accepting or registering a political proposition by voting. They contend that election is one of the means by which a society ay organize itself and make specified formal decisions they argue that where voting is free, it acts as a springboard for making rational decisions regarding the power relations in a society and as a method for political allegiance and sacrifice of the individual freedom.

There are debates which link election with exclusive individual choice. For instance, Eya(2003) recounts that election is seen as the selection of a person or persons for office as by ballot and making choice between alternatives. There are studies in the literature which argue that electoral politics in Nigeria has been likened to war fare (Adekanya, 1989; Ake, 2001; Ogundiya and Baba, 2007).

Equally, attentions in the literature have also been drawn to the prospects and challenges of democratization in Nigeria, Jega (2006, p.5) provides an outline of the "constitutive elements of the liberal democratic tradition' as follows; Representation: 'freedom to choose'---- Participation: 'getting involved'--- Responsive and responsible/accountable government, Equality before the law transparency and accountability in public conduct.

Debates espousing the persistent challenge of poor democracy culture and issues of democracy deepening have reinforced useful insights in understanding the persistent electoral crisis in post 1999 elections in Nigeria (Ogundiya and Baba, 2007) .Part of the challenge of democracy transformation and institutionalization of democracy culture has been the nature of the western styled democracy which is alien to the Africa traditional setting as Ake (1993) pointed out that "Western type" democracy is inappropriate that what is needed is that democracy which provides people with power to decide their affairs. This has been the consequence of democracy failures in Nigeria as the patterns of democracy has been riddled with imperfections and contradictions often at variance with the ideals of liberal democracy (Ibeanu, 2007)

Diamond(1997,p.12) identified constitutive dimensions of democracy deepening which include deepening democratic structures to make the ore liberal, accessible, accountable and representative; strengthening the formal institution of democracy; including parties, legislatures, and the judicial system and improving regime performance, both economically and politically by maintaining order, safeguarding liberty and combating corruption.

This informs and underpins the need for rethinking of both democracy and the electoral processes in Nigeria. Diamond, et al; (1999) had argued on the need for individual freedom as the basis for democracy as they contend that democracy encompasses extensive protection of individual and group freedoms, inclusive pluralism in civil society as well as party politics; civilian control of the military, institutions to hold officeholders accountable, and strong rule of law secured through an independent, impartial judiciary.

Election thus, remains an integral part of democracy akin to features such as popular sovereignty or one man one vote, individual liberty or human rights, rule of law or supremacy of the constitution, party competition, the active participation of citizens in public participation through their electoral representatives directly or indirectly (Appadorai,1975) . 
Understanding of election in Nigeria should transcend rhetoric and look at more practical terms and connection with everyday life of the people. Osaghae (2002.p.152) enumerates four related factors in Nigerian elections; (1) "the ethno-regional character of the political parties and the zero sum nature of politics which compels politicians to seek to secure power by any means, fair or foul;(2)the manner in which electoral commissions are composed which does not insulate it from partisanship;(3)the misuse of State owned media by incumbent parties to the disadvantage of opponents and (4) the partisan use of police and other security forces".

Regarding the conceptual exploration of security, the return to democracy in 1999 has increasingly created novel notions of understanding electoral security including the complexities associated with the carting of ballot boxes, buying of votes have resulted in concepts such as marketization or commodification of election (Ibeanu, 2007). The concept of election security suggests the existence of threats to the conduct of elections (Ighodalo, 2012). These security threats include malpractices such as: election rigging, snatching and stuffing of ballot boxes, political intimidation and assassination prior to, during and after elections (Ighodalo, 2012). Bawa (2013) argues that election security involves actions or steps taken to secure the electoral process.

Thus, security in electoral contexts can be conceptualized within the power relations imbedded in the dynamics of capitalist accumulation ethos in which the poor are used to articulate and actualize the political interest of the elite at the expense of the poor. Election is thus transformed into a mobilizing element not only for contesting of political office but also for "false consciousness" and access to state power within a context of competing and conflicting elite, in which various means (including violent) are devised as a modality for coordinating social forces to the interest of a particular group.

Beyond the usual notion of electoral competition and access to power, patronage becomes germane in the electoral system (Joseph, 1992). The electoral system in Nigeria reflect the dynamic realities inter elite interests and relations through which the acquisition of power is actualized.

Electoral security has also become a novel arena for demonstration of hooliganism conceptualized within the framework of arson and carting away of ballot boxes, use of fireworks and guns to intimidate perceived opponents. An important point in the Niger Delta is the use of local cult groups to victimize and terrorize the polity during election (Amadi, et al; 2016).

On the one hand, the political office seeker mediate the relations between the government and the youths they deploy to secure offices through violence and forceful means and the local populace who often sell their votes with little knowledge of the development implications(Ibeanu,2007).

The conceptualization of election creates a tendency to engage in a somewhat peculiar abstract analysis of the relations between election and security and its wider interface with development. This critical interface aims to establish causal connections with election and security.

Critical of understanding the extent to which elections are credible in Nigeria, Osaghae (et al; 2011 ) capture relations between the political elite and the electorate and argued that in the Niger Delta the political elites use the youths as political thugs and after achieving their selfish political interests abandon the youths, Amadi, et al; (2016) had argued that the elite fail to fully recognize the relevance of the youths in the economic development of the region, hence the perverse rise in youth restiveness in the region which had taken several forms in pre and post- election periods including militancy, abduction, vandalization of oil equipment's etc. This trend has eaten into the fabric of the region as a result and largely accounts for repeated electoral violence as the youths are largely unemployed (UNEP, 2011). On this basis, the concept of marketization of election through the buying of votes for elections become a common practice among the political elites who pay money to secures more votes (Ibeanu, 2007). Within this state of affairs re-moralizing the political space becomes a big problem as the flawed system seems to hold sway against constitutional provisions of the electoral act. In this particular circumstance unemployed youths could hold on to the material inducements from the political class for survival irrespective of how temporary (Osaghae, et al; 2011). The preferred approach of the youths become the use of all sorts of means to secure votes for their pay masters (Ibeanu, 2007) .HRW (2007) argued that insecurity in the Niger Delta has been an issue of increasing concern, it is much harder to see in this argument and similar studies how the guarantee of human security is, in any similar sense, driving the Niger Delta electoral process. As Olurode and Haamanga (2013) argued that election is a "security affair", getting it right boils down to economic development. Similar orientation can be found in the debates by Ibeanu and Jega (2007) who contend 
that election insecurity creates persistent systemic problems in the polity. It is clear that election has expanded to engulf the economic, rather than the entirely political conception of the practice. The logic of this strand stems from the logic of the fact that through political processes i.e. the election of the holders of political and economic powers (government) emerge and take key decisions encompassing economic and political. Thus the nexus between election, security and development is significant for a possible sustainable and equitable development of the Niger Delta and indeed Nigeria. This nexus is clear with the evidence of poor governance and refusal of the elites to make the votes of the electorates count, hence perverse rise in economic hardship, youth unemployment and poverty (Egwu, 2014). This is a serious development issue, with adequate electoral security, the choice of the people prevails and in turn political accountability and transparency could be actualized. Outside this, the supposed development might be negatively impacted. This contention that electoral security facilitates economic development has a meaningful and relevant interface with this research , and is an essential a part of a pro people and pro- development version of popular claims about the constitutive centrality of election and development nexus .

The key argument here is that security is key to a hitch free election and could systematically create to a large extent the desired fair playing ground for political office seekers. Jega(2006) contends that "election creates an avenue for competitive quest for elective offices . Boucher (2008) re-echoes that the effect of this is that many of these theorists work within what he calls the "charmed circle of ideology", which he uses to refer to "post-Marxism's tendency to reduce politics and economics to ideological struggles". Thus, from this perspective - and based on the expansive definition of election it is important to understand the need for security in the electoral process.

These problems as the available literature suggest, have been identified in the spate of killings in elections in Nigeria including similar issues such as hooliganism and thuggery that currently characterizes elections in Nigeria. For instance, Ibeanu and Jega (2007) argue that electoral crisis have been to a large extent the resultant effect of poor electoral system This suggests that despite "a firm rhetorical emphasis on election as central to democracy, there is a serious challenge linking the ongoing practice with effective security mechanism. The quest for acquisition of political power thus overrides electoral transparency with issues of bribery and electoral fraud as a common place since nascent democracy in Nigeria.

Ibeanu(2007) re-emphasizes the originally theoretical basis of the term " machine politics" to provide clearer understanding of what he termed "primitive accumulation of votes". He builds on Smith and Zurcher (1944,p.190) which argued that a political machine is an organization controlled by a boss or a small coterie of leaders which subjects party organization and public officials to its will and operates efficiently and ruthlessly in exploring governmental activities of nearly every sort for the private gain of its members". Mohammed (2007) attempts to transcend his rendition of "election" in which votes "must count". However, adequate apparatus to make votes count have been ineffectual resulting in irregularities. It is hard in my modest opinion to see how election could be free and fair without effective security apparatus. Security is integral to the conduct of free, fair and credible elections. The term election security seem not to have been satisfactorily put in proper scholarly perspective particularly in the developing societies. The security challenges have made politics generally a game for hoodlums (Joseph, 1992). Uganden (2010,p.90), argues that politics in Nigeria is particularly plagued with historically rooted ills that five decades of sovereign statehood have failed to eradicate. This points out the need for conceptual exploration of the concept of electoral security.

The concept of electoral security provides a controversial discourse as studies in electoral security and party politics largely depend on a less clear conceptualization of the term (Olurode, 2013). Security is of great concern to all human beings (Klare, 1996). The realist school conceive security in military terms suggesting various forms of military response to security threats. With the end of the Cold War, the military focus of security had a shift from a number of perspectives. There has been a number of perspectives on security particularly at the individual level. This has seen the emergence of election security debate, jostling for disciplinary space in political science, but most closely associated with the understanding of the dynamics and nature of the conduct of elections. Electoral security is notable for its rearticulating of some of the conventional questions of political participation pertaining to elections, particularly the relationship of the electoral body such as INEC in the particular case of Nigeria with the electorates and the security forces, in a distinct manner that puts the domain of security frontal in the electoral process. In particular, election security has challenged the existence of 
real or latent threats to free, fair and credible elections, and has argued instead for the guarantee of the security of all stakeholders during elections (Olurode, 2013; Bawa, 2013). This orientation has given rise to a number of conceptual debates, including the changing forms of election such as electoral violence (Bawa, 2013) ,codification of election and the buying of votes, carting of ballot boxes, shooting and arson during elections. These insecurity triggers arising from the conduct of elections have vitiated the understanding of election as organized and systematic mode of choosing political office holders under a party label .This creates analytical tension and contradictions which have been problematic in discourses on elections. The treatment of election in Nigeria as a "do" or "die" affair has resulted in increasing need to conceptualize it from the perspective of security. This is particularly important as security threats have created distortions in the conduct of elections in Nigeria (Ogundiya, 2000).

Debates on the emergent field of electoral security attempts to remedy deficiencies associated with the conduct of elections particularly on three fronts namely the protection of electoral materials, electoral officers and the electorates (Olurode, 2013; Bawa, 2013), as electoral security scholarship succeeds in providing novel scholarly arena to understand the dynamics of election and security, it fails to fully resolve the difficulties associated with the conceptual challenges of the term . This has resulted in attempts to examine studies linking election to security and to possibly create conceptual edge on the term electoral security and reaffirm the importance of such concepts in the electoral system of Nigeria. Thus, electoral security form part of a general vocabulary that people could deploy to understand the processes, practices and social relations which shape the electoral system. Yet, it has also been contentious as many political, economic and social factors that affect elections in security contexts have not been adequately examined. This opens this study to a number of future researches as well as important conceptual debates which have often affected the common basis of conceptual consensus on the term. Despite this, there is a widespread assumption that electoral security is integral to the success of elections.

Igini (2013) provided some theoretical conception of elections and argued that election security is integral to the integrity of the overall conduct of elections including the electorates electoral personnel election materials contestants election monitors; observers and other stakeholders who participate in the electoral process On his part, Alapiki (2000) argued that the abuse of incumbency power has been a major trigger of electoral insecurity.

According to Olurode and Haamanga (2013) electoral security constitute an integral element of the success of elections and represent an advance on electoral reform agenda in which the safety of the electorates are guaranteed before; during and after elections. This has given rise to the need for a critical re-engagement with electoral system in Nigeria beyond voting and being voted for in elections.

Equally, while greater attention in the literature is paid to election, the impact of electoral processes and outcome on development is poorly examined - from my research trajectories, - I do not believe that economic development could be actualized without credible elections. That is, the restructuring of modes of carting of ballot boxes, use of fireworks to scare voters, shooting at both perceived opponents and the electorates, buying of votes, deploying of youths and at times the police in favour of a particular political office seeker etc. These problems which have been a re-occurring challenge since the return to democracy have not been adequately discussed in the literature on elections in Nigeria. This becomes particularly important since democracy deepening has been often termed a missing agenda in Africa's democracy (Ake, 2001). What follows is the Niger Delta experience.

\section{The Niger DeLta EXPERIENCE}

Election and security challenges in the Niger Delta have been complex and contradictory. Violence and insecurity have been integral components of elections in Nigeria since the return to Democracy in 1999; the Niger Delta is no exception (Onwudiwe and Berwind-Dart, 2010). Although such claims that election has been a warfare (Ake, 2001) remains very common in the Niger Delta as in most parts of Nigeria with the consequence that election results are often contested by political opponents or settled in the court of law. Such practice and its transformation have not been adequately examined in the study of elections in the region.

The Niger Delta is made up of nine states namely Abia, Akwalbom, Rivers, Delta, Bayelsa, Edo, Imo, Cross River and Ondo. There are a number of factors linked to the persistence of electoral violence 
and insecurity in the region. First as a coastal oil rich region, the quests for the control of oil resources have been at issue, resulting in violent conflict for political office seekers. However , the use of youths as thugs during elections since the return to democracy in 1999 have resulted in proliferation of Small Arms and Light Weapons(SALWs) in the region and account for shootings in elections (Human Rights Watch,2004).

In the 2003 elections, there were a cycle of widespread violence and insecurity emanating from inter and intraparty clashes, this spread across areas such as Uyo in Akwa Ibom State, Warri area in Delta State, Yanagoa in Bayelsa State and pervasive in Port Harcourt in Rivers State. There were similar records of violence including shootings in Port Harcourt and some rural areas notably Buguma. More critical have been the insecurity threats posed by politically motivated killings, attempted assassinations, social unrest and perverse shootings (Onwudiwe and Berwind-Dart, 2010). Similarly, Oddih (2007) reports that the 2003 elections were particularly marked by dissatisfaction by candidates, voters and observers. Onwudiwe and Berwind-Dart, (2010) identified interparty feuding as one of the dimensions of electoral violence. That the feud is fought by elite-sponsored militias or directed at the elites themselves citing the instance of July 2006, when the PDP gubernatorial aspirant for Lagos, Chief Funsho Williams, was murdered in his home by hired assassins. Similar murder experience included Chief Marshal Harry of the ANPP and Chief A K Dikkibo of the PDP both from Rivers State.

Also "gang violence" has been deployed to explain dynamics of electoral violence in the Niger Delta. This involves the use of several gangs and cult groups by the political elite. In Rivers State, Human Rights Watch (2008) reports that during the 2003 election cycle, state government officials working with then-Rivers State Governor Peter Odili and then-Federal Minister of Transportation Abiye Sekibo armed and hired criminal gangs to ensure the successful rigging of Rivers' polls in favour of the People's Democratic Party. The Niger Delta electoral violence has also been linked to corruption and unaccountable nature of politics in the region (Human Rights Watch, 2008).

In the 2007 elections there were massive violence and killings in the Niger Delta (Egwu, 2014) Nigerian voters were denied the chance to count and be counted and, disturbingly, the trend has worsened. National and international monitors observing the 2007 polls referred to them as an undemocratic charade, while Freedom House declared them the worst in Nigeria since the end of military rule in 1999 (Freedom House, 2008) .

In 2009, to douse the political tension in the region, President Yar'Adua granted amnesty to the Niger Delta militants. However, in these accounts, the insistence upon electoral transformation which requires radical collective efforts that could ultimately lead to a new political culture and reformed electoral process including the long held grievances between the Itsekiri and Urhrobo in Delta state remained less transformed. A related account of post -election killing was in 2010 when popular Niger Delta militant Saboma George, accused of past election rigging, was killed in Rivers state (Ekeinde, 2010).

The 2011 post-election violence is seen by many as the bloodiest incident of electoral violence in Nigeria's history including the Niger Delta region(HRW, 2011).Electoral violence in the region as Adoke(2011)recounts include shooting, killings, arson, wanton destruction of property, usually perpetrated by officials and/or supporters of different political parties.

The 2015 elections marked a major turning point in Nigeria's democracy, Muhammadu Buhari (APC) won the Presidential elections on March 28, defeating incumbent President Goodluck Jonathan (PDP). Equally, the Niger Delta experienced massive electoral violence following the rise in local cultism in the region. For instance, the conduct of elections in some states of the Niger Delta was meshed with gangs and local cult groups. Such as in Rivers State where two dominant rival cult groups namely Icelanders and Greenlanders remained in perpetual struggle for supremacy. Also in Rivers State, more than in any of the other state, cult groups took sides in the election, including allegations that the Icelanders and Greenlanders have been involved in "political thuggery." Clashes between cult groups have also been reported in Obio/Akpor and Degema Local Government Areas although these clashes have not always been directly election-related. Other cases of election violence include the reported attack on the All Progressives Congress (APC) headquarters in Okrika, the shooting of APC supporters in Khana, another shooting incident targeting a PDP campaign team in Abua/Odual, the destruction of an APC party office in Andoni, the disruption of an APC rally in Port Harcourt, another 
political rally that turned violent in Asari-Toru, as well as the hijacking of PVCs and the destruction of campaign materials.

In February, following the 2015 elections in the Niger Delta, there were incidence of violent attacks. For instance, in the 2015 general elections in Rivers State a corps member on adhoc electoral office assignment was killed ; similarly in the rerun election of December 10, 2015 a police officer was beheaded (Adebayo,2016) . These critical issues require novel security apparatus. This gives rise to several analytical difficulties in understanding the concept and problems of electoral insecurity. Also in Rivers State courts in Degema, Isiokpo, and Port Harcourt in Rivers State were targeted with explosives, although no fatalities were reported for the incident.

In Akwalbom State ahead of the 2015 general elections, reports suggested that PDP supporters in Uyo LGA, beat an APC supporter to death after the victim was caught tearing down their political posters (HRW,2015). This was then met by a reprisal attack from APC supporters, which left five people injured. Other pre-election incidents included thugs thought to be affiliated with PDP setting two APC cars on fire in Oron LGA, and at least three deaths at a PDP political rally in Etinan LGA (HRW, 2015).

In Bayelsa State, there were also several reports of destruction of campaign materials by youths and thugs in Brass, Kolokuma/Opokuma, and Nembe Local Government Areas (LGAs), exacerbating tensions. Tensions between parties and candidates escalated to violence on several occasions, particularly in Sagbama, Nembe, Ekeremor, and Southern Ijaw LGAs, often involving suspected paid thugs (HRW, 2015).

In Delta State, similar election-related conflict ensued and included multiple reports of rising tensions sparked by the destruction of campaign materials by the supporters of opposing parties in Sapele, Udu, and Uvwie LGAs. Clashes involving youths and political thugs were reported in Sapele, Uvwie, and Warri South. There have also been several reports of frustration and confusion surrounding the process of PVC distribution (Aniekwe and Kushie, 2011;HRW, 2011).

Communal violence included a clash between Ijaw and Urhobo communities in Bomadi and Ughelli South LGAs that reportedly killed one person, and violence between pastoralists and farmers in Ughelli North. In Warri South a land dispute between two communities escalated to violence. Several other cases of communal violence were also reported during this period, including one in Ethiope East which resulted in multiple injuries. Criminal violence included several clashes between cult groups, especially in Warri South, as well as in Ughelli North and Ika south in which several were killed.

In others, such as Warri in Delta State political rallies have escalated to violence in several parts of the region. The lives of both the voters and INEC officials are often put at risk including logistical challenges involving the distribution of Permanent Voter Cards (PVCs) (HRW, 2015).

Against the background of these violent experiences there is need to emphasize the basis for security. For instance, in parts of the Niger Delta States, Olurode (2013) reports that there is hardly any elections in the region with adequate security apparatus. This has resulted in incidence of insecurity including killings and shootings during the 2011 elections as a result of struggles and counter struggle to cart away ballot boxes. Bawa (2013) attributes this to the perverse rise in thuggery. Similar debates contend that elections have been often associated with the term such as "deliver" "liberate" or "break into" pointing to a number of terms used to perpetuate electoral irregularities as "assignments" or "tasks" given to alleged party loyalists or thugs to capture votes by all means for political office seekers. This model forces party loyalists to go the extra miles including using both monetary inducements and naked force to secure votes in elections. And further compels the electorates in a false choice between accepting money, being systematically disenfranchised or being killed.

\section{CONCLUSION AND RECOMMENDATIONS}

The contest for political office in the Niger Delta has thus been riddled with conflicts and killings as the foregoing discussion suggests. Against the background of the discourse in this article, there has been a deeper understanding of the conceptual issues raised on election and security as well as the patterns of threats associated with electoral insecurity. A number of studies as discussed have recently been undertaken to understand the dynamics of Nigeria's election since at least 1999 pointing to insecurity. This growing concern reflects the need for transformation of insecurity in Nigerian 
elections. A rethinking of the electoral process, reviewing key trends in its conduct and suggesting future research agendas that might draw fruitfully on electoral security reforms have been a missing research agenda.

Electoral insecurity problems has often affected democracy deepening in Nigeria (Hassan, 2013). Thus, the return to a democratic rule has been useful in setting of new research agendas on electoral system and security in Nigeria such as the electoral act, however the aspect of improved security in the conduct of elections have been at issue with theoretical and policy dynamics( Bawa, 2013) .

Several studies have either provided an overview or critique of the Nigerian electoral system or mechanisms to improve the Nigerian electoral process (Hassan, 2013). However the literature reviewed so far point to the fact that few studies have already been done in the context of election security. For instance, Onyekpere (2013) had argued on the need for election security finance, thus suggesting a distinct attention to provision of monetary resources for effective institutionalization of election security. Olurode (2013) had set out in more details the ways in which the field electoral security had been elusive in the Nigerian electoral system and has, challenged the prevailing electoral process. Dudley (1981) argues that earlier works in electoral system in Nigeria, present an underused resource in the context of effective electoral process, and argues instead for the need to provide salient ways of improving the electoral practices in an ore results oriented and people based approach. The aim particularly is to enhance the theoretical basis of electoral insecurity transformation, and provide for a clearer working out of its policy and research relevance. Much of this perspective have been useful in redefining a research agenda that advocates for electoral security paradigm to construct a novel conceptual whole that could recreate the dominant orientation towards violent free electoral practices .The argument here is to provide an alternative way of thinking about election, one which deconstructs the dominant notion of the process as a warfare (Ake, 2001; Human Rights Watch, 2008).

This paper suggests that electoral security is integral to the management of elections without which the over -all success of the election might not be actualized. Essentially, studies concerned with the issues of addressing the relationship between election and massive insecurity and the threats which electoral insecurity pose to human life seem scant, pointing to the urgency of effective electoral insecurity mitigation strategies.

Thus, while election plays key roles in legitimizing the emergence of political office seekers, it is recommended that it should be conceptualized as a- security issue. This policy gap partly gave rise to the present research and recent scholarship seeking to bring election into the mainstream security debate (Olurode, 2013; Bawa, 2013; Hassan, 2013). Similarly, the political system is imagined to comprise largely only political actors including the electoral officers, electorates and the political office seekers, leaving out the security component without which free; fair and credible elections cannot be guaranteed. This include largely the human component who are primary the basis of the election.

From the foregoing, the alternative electoral perspective which views election to be termed free, fair and credible to the extent that security is maintained in line with stipulated law and order seems less theorized. In the views propagated in this study, the latter perspective which should be more expansive as a particular mode of understanding the credibility of elections in practice and policy have not been sufficiently explored in the literature. This is critical as it is premised on economic, political and social development of the polity by conceiving election largely as a development instrument being the fulcrum for electing political office seekers. With the increasing security challenges ahead of the 2019 general elections, one of the foremost efforts at institutionalizing election security is to set out requisite mechanisms to check killings and similar insecurity problems associated with elections. This study among others suggest that both international and local observers as well as various election monitoring groups and similar anti-graft agencies should be involved as violence in the Niger Delta elections is linked to corruption. Thus, for those who recognize the need for adequate security in electoral practices to protect the individuals, electoral officers and materials, the need for security remains ever critical.

Finally, the basis for election and security nexus cannot be over emphasized .The reviewed literature creates novel engagement to further examine the importance of security in Nigeria's elections which has been problematic. Thus, new sets of research agenda and approaches are suggested, as concrete 
tools to, conceptually grasp the social relations of the electoral system. This also creates the image of electoral justice and equity against the prevailing "selection process" in which party officials hijack the electoral process including voting materials and vote in place of the electorates. Such practices which are at variance with the democratic process require urgent policy attention.

\section{REFERENCES}

Adebayo H. (2016). INEC, Police, Army culpable in Rivers elections violence - Report. Premium Times.

Adekanye, J. (1989). (ed.) the Military, Social Classes, and Revolution, Special Issue of Studies in Politics and Society No. 5, Ibadan: Vantage Publishers, for Nigerian Political Science Association (July), pp. 178.

Ake, C .(2001).Democracy and Development in Africa. Ibadan Spectrum

Ake, C .(1996). Democracy and Development in Africa. Washington: Brookings Institution.

Ake C .(1993).Ake, C .(1993). The Unique Case of African Democracy International Affairs Vol. 69, No. 2:239-244.

Alapiki, H. (2000).Politics and Governance in Nigeria Sprng field Publishes Amadi, L.( 2016). Sustainable Rural Livelihoods: Elusive Post-Colonial Developmentalism in Nigeria,1960-2014 A paper presented in an International Conference on Africa Since Independence: Promise, Pugnacity, and Failure in the Post- Colonial Contexts: in Honour of Professor Akanmu G. Adebayo August 3-5, 2016 University of Ibadan, Ibadan, Nigeria.

Amadi, L, Imoh-Itah,I, Obomanu, F.(2016).Oil: Niger Delta and The Making of Militia Capitalists: a theoretical assessment. International Journal of Social Science and Humanities Research Vol. 4, Issue 1, pp: (172-184).

Aniekwe, C and Kushie, J. (2011). Electoral Violence Situational Analysis: Identifying Hot Spots in the 2011 General Elections in Nigeria. National Association for Peaceful Elections in Nigeria (NAPEN) Abuja pp1-47

Appadorai, A. (1975). The Substance of Politics New Delhi: Oxford University Press

Bawa, I. (2013).Legal Constraints in Election Secuirty in Nigeria in IOlurode L (ed;) Election Security in Nigeria: Matters Arising Fredeich Ebert -Stifing (FES).Abuja

Boucher, J. (2008). The charmed circle of ideology: A critique of Laclau \& Mouffe, Butler \& Žižek. Melbourne: Re. press.

Commission on Human Security (CHS). (2003). Human Security Now, New York: Commission on Human Security.

Dauda, G.( 2007).Transition without Change: Election and Political(In)stability in Nigeria in Jega A and Ibeanu O (eds;) (2007) Elections and the Future of Democracy in Nigeria Nigerian political Science Association (NPSA).

Debiel, T and Werthes, S. (2006). Human Security on Foreign Policy Agendas: Changes, Concepts and Cases, Duisburg, Germany: Institute for Development and Peace, INEF at the University of Duisburg-Essen.

Diamond L, Jonathan H, Juan L and Lipset S (eds).(1999).Democracy in Developing Countries London :Lynne Rienne Publishers

Diamond, L. (1997). Consolidating Democracy in the Americas Annals of the American Academy of Political and Social Science AAPSS; 550 March pp12-41

Dudley,B.(1981). The Nigerian Elections of 1979: The Voting Decision. Journal of Commonwealth and Comparative Politics, Vol. XIX, No.3.

Easterlin, R.(1981).Why Isn't the Whole World Developed? Journal of Economic History pp 117

Egwu, S. (2014).Farewell to Electoral to Electoral Authoritarism? Pathway to Democratic Consolidation in Nigeria in Nnnabugwu M (ed) The State and the Global Economic Crisis Nigerian Political association.

Ekeinde,A. (2010).“Police Recover Body of Former Gang Leader,” Next, August 27

European Union Election Observation mission. (2003). "Final Report on the National Assembly, Presidential, Gubernatorial and state Houses of Assembly Elections" Available at www eueonige ria.org. 
Eya, N.(2003).Electoral Processes, Electoral Malpractices, and Electoral Violence, Enugu Sages Publications Nigerian Ltd.

Fischer, J. (2002). Electoral Conflict and Violence IFES, Washington, D.C.

Freedom House, (2008) "Freedom in the World 2008-Nigeria," www.freedomhouse.org/template. $\mathrm{cfm}$ ? page $=22 \&$ year $=2008 \&$ country $=7461$.

Fukuda-Parr, S and Messineo, C. (2012). 'Human Security: A Critical Review of the Literature', Centre for Research on Peace and Development (CRPD) Working Paper No. 11 (Leuven: Centre for Research on Peace and Development)

Garuba, D. (2007).Transition without Change: Elections and Political (In)stability in Nigeriain Jega A and Ibeanu O (eds;) (2007) Elections and the Future of Democracy in Nigeria Nigerian political Science Association (NPSA).

Gwinn, R and Nortan, P. (1992).The New Encyclopedia Britanica Chicago: University of Chicago 'Press.

Hassan, A.(2013) .Security Challenges in Kenyan Elections in Olurode L (ed) Election Security in Nigeria: Matters Arising Fredeich Ebert -Stifing (FES). Abuja December 12,

Hubert, D. (2001) .Human Security: safety for the People in a Changing World in Beyond Conflict Resolution: Managing African Security in The $21^{\text {st }}$ Century Akindele R and Ate B eds; Ibadan :Vantage Publishers

Human Rights Watch. (2003 ). The Warri Crisis: Fuelling Violence Vol. 15, No.18 (A) November .

Human Rights Watch. (2004). Nigeria's 2003 Elections: The Unacknowledged Violence, Human Rights Watch, New York.

Human Rights Watch. (2007). "Nigeria: Polls Marred by Violence, Fraud," April 17, 2007, www.hrw. org/ en/news/2007/04/15/nigeria-pollsmarred-violence-fraud

Human Rights Watch. (2008). "Politics as War: The Human Rights Impact and Causes of PostElection Violence in Rivers State, Nigeria," March 26.

Human Rights Watch. (2015).Nigeria: Post-Election Violence Killed 800 May

Ibeanu, O. (2007). Elections and the Paroxysmal future of Democracy in Nigeria in Jega A and Ibeanu O (eds;) (2007) Elections and the Future of Democracy in Nigeria Nigerian political Science Association (NPSA).

Ibeanu, O and Jega, A (eds).( 2007).Elections and the Future of Democracy in Nigeria Political Science Association.

Igbuzor, O. (2010) .Electoral Violence in Nigeria. Asaba, Action Aid Nigeria.

Ighodalo, A. (2012).Election Crisis, Liberal Democracy and National Security in Nigeria's Fourth Republic. European Scientific Journal vol. 8, No.26

Igini, M.(2013). Election Security in Theory and Practice in Olurode L (ed) Election Security in Nigeria: Matters Arising Fredeich Ebert -Stifing (FES).Abuja

Jega, A. (2006).Democratization in Nigeria: Problems and Prospects; Claude Ake memorial Lecture; Port Harcourt: Centre for Advanced Social Science

Joseph, R. (1992).Democracy and Prebendal Politics in Nigeria .The Rise and Fall of Second Republic. Ibadan: Spectrum Publishers.

Jolly, R and Ray, D. (2006).National Human Development Reports and the Human Security Framework: A Review of Analysis and Experience, Brighton: Institute of Development Studies.

Kaldor, M. (2007). Human Security, Cambridge: Polity Press.

Kaldor, M. (1999). New and Old Wars: Organized Violence in a Global Era, Cambridge: Polity Press

Khong, Y. (2001). 'Human Security: A Shotgun Approach to Alleviating Human Misery?', Global Governance, 7(3), pp. 231-236

Klare, M. (1996).Redefining Security The new Global Schisms" Current History Vol 95, No 602

Martin, M and Owen, T. (2010). 'The Second Generation of Human Security: Lessons from theUN and EU Experience', International Affairs, 86(1), pp. 211-224. 
Mohammed, K. (2007).Counting the Votes and Making the Votes Count lessons from Adamawa State in Jega A and Ibeanu O eds;(2007)Elections and the Future of Democracy in Nigeria Nigerian political Science Association (NPSA).

Nwabueze, B. (1993). The Electoral Process and the 1989 Constitution in Uezuluike: Democracy B Nwokeke P. and Jayum A (2011) The Electoral Process and Democratic Consolidation in Nigeria Journal of Politics and Law Vol. 4, No. 2 pp128-138.

Oddih, M. (2007).Electoral Fraud and the Democratic Process: Lessons from the 2003Elections in Ibeanu $\mathrm{O}$ and Jega A (eds). Elections and the Future of Democracy in Nigeria. Nigeria Political Science Association.

Ogundiya, S. (2000). The Legitimacy Crisis in Nigeria: A Two Regime analysis unpublished Ph.D Thesis submitted to the Department of Political Science, Faculty of Social Sciences University of Ibadan.

Ogundiya, I.(2003).Electoral Violence and the Democratization project :The Nigerian experience in Olosupo BA(ed)Electoral Violence in Nigeria: Issues and Perspectives; Lagos: FES.

Ogundiya, I and Baba, T. (2005). Electoral Violence and the Prospects of Democratic Consolidation in Nigeria in Onu G and Momoh A eds; Elections and Democratic Consolidation in Nigeria.

Olurode , L. (2013). Introduction in Olurode L (ed) Election Security in Nigeria: Matters Arising Fredeich Ebert -Stifing (FES).Abuja

Olurode,L and Haamanga, M. (2013). Employment of Security Personnels in Elections Challenges from Field Experience in Olurode L (ed) Election Security in Nigeria: Matters Arising Fredeich Ebert -Stifing (FES).Abuja

Onwudiwe, E and Berwind-Dart, C.(2010).Breaking the Cycle of Electoral Violence in Nigeria Special Report United States Institute of Peace.

Onyekpere,E.(2013 ).Eletion Security Finance in Olurode L (ed) Election Security in Nigeria :Matters Arising Fredeich Ebert -Stifing (FES).Abuja.

Osaghae, E. (2002).Crippled Giant: Nigeria Since independence Ibadan :PEFS.

Osaghae, E, Ikelegbe A, Olarinmoye O and Okhonmina, S. (2011). Youth Militias, Self Determination and Resource Control Struggles in the Niger-Delta Region of Nigeria. Dakar, CODESRIA, Research Report n ${ }^{\circ}$ 5, $96 \mathrm{p}$

Report of the Political Bureau (1987) Federal Republic of Nigeria MAMSER.

Smith, E and Zurcher, A .(1944). A dictionary of American Politics, NY: Barnes and Noble

Tadjbakhsh, S and Chenoy, A. (2007). Human Security: Concepts and Implications (London \& New York: Routledge.

ulHag, M. (1971). Employment and Income Distribution in the 1970s: A New Perspective Development Digest October

ul Hag, M. ( 1995). Reflections on Human Development (New York: Oxford University Press, pp 115.

United Nations (UN). (1994). United Nations Development Report, New York: United Nations Development Programme.

United Nations (UN). (2004). 'A More Secure World: Our Shared Responsibility', Report of the High-level Panel on Threats, Challenges and Change, New York, United Nations Foundation.

UNEP (United Nations Environment Programme). (2011). Environmental Assessment of Ogoniland, Nairobi Kenya.

Uganden, I. (2010). Political Accountability in Nigerian Governance: Implications For Long-Term Development" Journal of Social Science and Public Policy 2(-) 86-95

Zasha, J, Mustapha A and R Meyer. R.(2007). A Lessons Learnt: Exercise following the April 2007 elections in Nigeria. LELEX Final Report, November. Abuja: UNDP. Joint Donor Basket Fund 